\section{Hoophouse Contributions to Economic Viability: Nine Michigan Case Studies}

\author{
David S. Conner ${ }^{1,4}$, Kurt B. Waldman ${ }^{2}$, Adam D. Montri ${ }^{3}$, \\ Michael W. Hamm², and John A. Biernbaum ${ }^{3}$
}

AdDitionAL INDEX WORDS. high tunnel, farm economics, vegetable production

Summary. Relatively low-cost season extension structures have the potential to contribute to farm economic viability in temperate climates by providing a means to continue sales beyond the limits of outdoor-only field production. These structures, commonly called hoophouses, high tunnels, passive solar greenhouses, or unheated greenhouses, allow for the extension of heat-tolerant (warm season) crops on both ends of the production time frame and at winter harvesting of cold-tolerant (cool season) crops. In this study, results are presented from a multiyear investigation into the economic impacts of year-round production and harvesting, with a focus on profitability of the structure and crop production as a whole. The results of case studies from nine Michigan farms reveal a very broad range of outcomes across farms in construction time, labor allocation and returns, and gross and net revenue. The economic implications of farmer use, including projected investment payback time, are discussed.

$\mathrm{N}$ umerous season extension techniques such as heated greenhouses, cold storage, root-cellars, cold-frames, variety selection, transplant production, and various means for food preservation have been used by farmers in temperate climates to ensure food availability in months when outdoor production is restricted by temperature, snow, wind, and light-level influences on plant growth and development. For farmers in states such as Michigan, much of which is located in the U.S. Department of Agriculture climate zones 4 and 5 , the short growing season also limits income potential. For the majority of farmers, the short growing season typically means that farm income must occur from April to October. For the remainder of the year, farm income is either low or nonexistent. Besides additional cash flow to

Research and outreach efforts are supported by The National Research Initiative of the U.S. Department of Agriculture Cooperative State Research, Education and Extension Service, grant number 2006-55618-16922; the Michigan Agricultural Experiment Station; and the C.S. Mott Chair in Sustainable Agriculture Endowment.

${ }^{1}$ Department of Community Development and Applied Economics, University of Vermont, 146 University Place, Burlington VT 05405

${ }^{2}$ Department of Community, Agriculture, Recreation and Resource Studies, Michigan State University, 131 Natural Resources, East Lansing, MI 48824.

${ }^{3}$ Department of Horticulture, Michigan State University, 288 Plant and Soil Science Building, East Lansing, MI 48823

${ }^{4}$ Corresponding author. E-mail: davidsconner@gmail. com. the farm, additional benefits of yearround or extended-season harvesting and distribution for farmers include: the potential for reduction of extreme summer workloads while maintaining, or enhancing, farm income as labor and sales are spread over more months; the ability to maintain markets and customers that otherwise require reestablishment each season; and increased physical activity in winter months. The hoophouse, as a yearround season-extension technology, provides a relatively low-cost means to extend harvesting with an opportunity to increase farm gate sales and farm viability.

CHALlENGE OF FARM PROFITABILITY. The need for enhanced farm profitability is clear. For example, in 2007, 56\% of Michigan farms and $53 \%$ of U.S. farms reported net losses (USDA, 2007a, b). An important strategy for small- or medium-sized businesses is product differentiation butes (Lancaster, 1974; Porter, 1985). that meets demand for specific attri-
Products grown in the hoophouse have the potential to meet the demand for "locally grown" and "fresh" that have increased in recent years. Locally grown vegetables are not only perceived by many to be more fresh and have a better taste but also their sales may have indirect benefits such as potential decrease in transportation cost, fuel use, pollution, infrastructure wear, and support for local farmers and overall benefit to state and regional economies (Conner et al., 2008; Swenson, 2006). Farmers can use hoophouses to supply many items well beyond regional fieldgrown availability, providing a scarcer product that would presumably bring a premium price. This cash flow could prove especially important in the late fall, winter, and early spring when such opportunities are limited.

CURRENT hoOphouse eFForTs. Hoophouse literature primarily focuses on an overview of construction, production, and extension efforts to promote the usage of these structures (Blomgren and Frisch, 2007; Carey et al., 2009; Demchak, 2009; Giacomelli, 2009). There have been more than 350 high tunnels constructed in Pennsylvania and the surrounding states since 1999 (Lamont et al., 2002). Prominent books by growers using hoophouses are also of the how-to nature (Byczynski, 2003; Coleman, 1992, 1995, 2009; Wiediger and Wiediger, 2003). The body of literature focusing on hoophouse economics is less prevalent and often focuses on the economics of a specific warm-season crops such as tomato (Solanum lycopersicum), pepper (Capsicum annuum), cucumber (Cucumis satious), or brambles ( $R u$ bus ssp.) (Cheng and Uva, 2008; Heindenreich et al., 2008; Waterer, 2003).

Another focus is on-farm enterprise budgets. Focusing on a single crop fails to capture the decisions that direct market vendors must make to

\begin{tabular}{lllc}
\hline $\begin{array}{l}\text { Units } \\
\text { To convert U.S. to SI, } \\
\text { multiply by }\end{array}$ & U.S. unit & SI unit & $\begin{array}{l}\text { To convert SI to U.S., } \\
\text { multiply by }\end{array}$ \\
\hline 0.4047 & $\mathrm{acre}(\mathrm{s})$ & $\mathrm{ha}$ & 2.4711 \\
0.3048 & $\mathrm{ft}$ & $\mathrm{m}$ & 3.2808 \\
0.0929 & $\mathrm{ft}^{2}$ & $\mathrm{~m}^{2}$ & 10.7639 \\
2.54 & inch(es) & $\mathrm{cm}$ & 0.3937 \\
0.4536 & $\mathrm{lb}$ & $\mathrm{kg}$ & 2.2046 \\
4.8824 & $\mathrm{lb} / \mathrm{ft}^{2}$ & $\mathrm{~kg} \cdot \mathrm{m}^{-2}$ & 0.2048 \\
0.0254 & $\mathrm{mil}$ & $\mathrm{mm}$ & 39.3701
\end{tabular}


offer a diversified product line. For example, a single hoophouse full of tomatoes may result in the highest gross sales, but if the vendor takes only tomatoes to the farmers market, their offerings may limit their customers. Additionally, although extrapolating sales based on research plot yields and various market prices provides a reference point, it is often based on selling $100 \%$ of marketable yields. This provides the value of the product and the upper bound for potential income, but does not account for actual sales in a competitive marketplace.

Four recent enterprise budgets for hoophouse tomatoes are summarized in Table 1 (Blomgren and Frisch, 2007; Bullen, 2009; Foord, 2004; Upson, 2009). Reported yield varies by $46 \%$, assumed prices vary by $150 \%$, while net revenue per square foot varies by $94 \%$. Only one study (Blomgren and Frisch, 2007) was apparently done on farm than on a research plot. This variation occurred even in hoophousegrowing environments with universitytrained enumerators.

The objectives of this study are to present the economic performance of nine hoophouse case studies on Michigan farms, including revenues, costs, and labor hours associated with growing vegetables in a hoophouse over the first $21 / 2$ years of adoption. Specific research questions to be answered include: 1) How much time did it take for an inexperienced crew provided with guidance to construct a hoophouse? 2) What gross and net incomes did the case study farmers earn from the hoophouse? 3) Given these net revenues, how long would it take for the case study farmers to earn back initial investment in the hoophouse structure? 4) What are the returns to owner-operator and family labor in the hoophouse? 5) How was labor allocated across the calendar by the case study hoophouse farmers?

\section{Materials and methods}

A total of nine farmers, three from each of three regions in Michigan (Fig. 1), were selected to participate in this project. The participating farmers were selected with assistance of three community partners who were instrumental in the overall project design. One partner was a Michigan State University (MSU) Extension Educator from Washtenaw County in southeastern Michigan; another is a MSU County Extension Director in the eastern Upper Peninsula of Michigan; and the third is the founder of a farmers' market in western Michigan. Each community partner was asked to select and contact three farmers in his area who marketed primarily at a farmers' market to participate in the project, so that evaluation of the extended season production on the farmer's market activity could be considered. Once selected, the farmers were contacted by the MSU team to arrange for delivery of the hoophouse and scheduling of training sessions. Numbers have been assigned to each farmer, with $\mathrm{Fl}$, $\mathrm{F} 5$, and F8 representing farmers from the eastern Upper Peninsula of Michigan; F2, F6, and F7 represent farmers from central western Michigan; and farmers F3, F4, and F9 are from southeastern Michigan.

A summary of participating farmer's demographics and measures and description of farm businesses and farming experiences are presented in Table 2 . There was wide variation among the nine participating farmers in age (ranging from 19 to 69 years with an average of 47 years) and level of education (ranging from General Equivalence Diploma to Master of Science degree). Everyone in the group had some farm experience, but only five of the nine farmers had grown in a greenhouse before. Two farmers had very large vegetable farms and sent vendors to many farmers' markets, while the majority of growers cultivated less than two acres of vegetable crops on outdoor acreage and sold at only onefarmers'market. Themedianhousehold income per county where hoophouses were located range from $\approx \$ 40,000$ to $\$ 60,000$ per year.

Each farmer received a 30 -ft-wide by 96 -ft-long hoophouse (Nor'easter; Rimol Greenhouse Systems, Hooksett, $\mathrm{NH}$ ), provided through grant funds, which was constructed on their respective farms. This hoophouse was selected for longevity and to withstand high snow load and wind expected at the sites. It consists of 1.9-inch-diameter rafters on 4 -ft spacing, with trusses on each rafter, extended ground posts, double-layer inflated 6-mil polyethylene covering, 6-mil single-layer polyethylene on metal-framed endwalls, wood hipboards and baseboards, manual roll-up sides, and thermostatically controlled 51 -inch square louvered vents at the gabled peak ends. Extended 6-ft ground posts provided a sidewall height of $\approx 6 \mathrm{ft}, \mathrm{l} \mathrm{ft}$ from the edge (2-ft ground post and 4-ft roof bow), which allowed aisles to be located on the edges of the structure where it is coldest in the winter. In addition, electrical metal tubing conduit was provided to construct a frame for an interior covering (4-mil polyethylene), which is advantageous to growing throughout a Michigan winter (illustrated in Blomgren and Frisch, 2007). The materials for this particular structure cost $\approx \$ 10,000$; hoophouses of many sizes and price ranges are available.

Authors (Montri and Biernbaum) led one training build ( $3 \mathrm{~d}$ ) on one of the participating farms in each region; participants in that region were required to attend. Participants were then expected to aid one another in

Table 1. Comparison of results of four hoophouse tomato enterprise budgets reported in the literature (Blomgren and Frisch, 2007; Bullen, 2009; Foord, 2004; Upson, 2009).

\begin{tabular}{|c|c|c|c|c|c|c|c|}
\hline State & $\begin{array}{c}\text { Area of hoophouse } \\
\left(\mathrm{ft}^{2}\right)^{\mathrm{z}}\end{array}$ & $\begin{array}{c}\text { Yield } \\
\left(1 \mathrm{~b} / \mathrm{ft}^{2}\right)^{\mathrm{y}}\end{array}$ & $\begin{array}{l}\text { Price } \\
(\$ / 1 b)^{x}\end{array}$ & $\begin{array}{l}\text { Revenue } \\
\left(\$ / \mathrm{ft}^{2}\right)^{\mathrm{w}}\end{array}$ & $\begin{array}{c}\text { Variable costs } \\
\left(\$ / \mathrm{ft}^{2}\right) \\
\end{array}$ & $\begin{array}{l}\text { Fixed costs } \\
\left(\$ / \mathrm{ft}^{2}\right)\end{array}$ & $\begin{array}{c}\text { Net revenue } \\
\left(\$ / \mathrm{ft}^{2}\right) \\
\end{array}$ \\
\hline North Carolina & 2,880 & 2.00 & 2.00 & 4.00 & 1.28 & 0.60 & 2.13 \\
\hline Minnesota & 1,920 & 2.54 & 1.25 & 3.18 & 0.77 & 0.38 & 2.03 \\
\hline Vermont & 2,016 & 1.75 & 2.50 & 4.38 & 1.82 & 0.40 & 2.15 \\
\hline Oklahoma & 1,360 & 2.33 & 1.00 & 2.33 & 0.66 & 0.56 & 1.11 \\
\hline
\end{tabular}

${ }^{\mathrm{z}} 1 \mathrm{ft}^{2}=0.0929 \mathrm{~m}^{2}$.

$1 \mathrm{lb} / \mathrm{ft}^{2}=4.8824 \mathrm{~kg} \cdot \mathrm{m}^{-2}$.

x $\$ 1.00 / \mathrm{lb}=\$ 2.2046 / \mathrm{kg}$.

${ }^{\mathrm{w}} \$ 1.00 / \mathrm{ft}^{2}=\$ 10.7639 / \mathrm{m}^{2}$. 
the construction of the additional two houses in their region, with the opportunity to call and email the authors for technical assistance in the form of conversation, pictures, and site visits, as necessary. In exchange for the structure, farmers agreed to record and report all revenues, costs, and labor hours associated with hoophouse growing. The structures will remain on the farms following completion of this project.
Farmer also agreed to participate in annual interviews describing their experiences, lessons learned, and challenges.

Following a training session outlining the purpose, objectives, and methods for data collection, farmer collaborators were provided with necessary materials and tools to create records of daily practices. Farmers read and signed consent forms granting

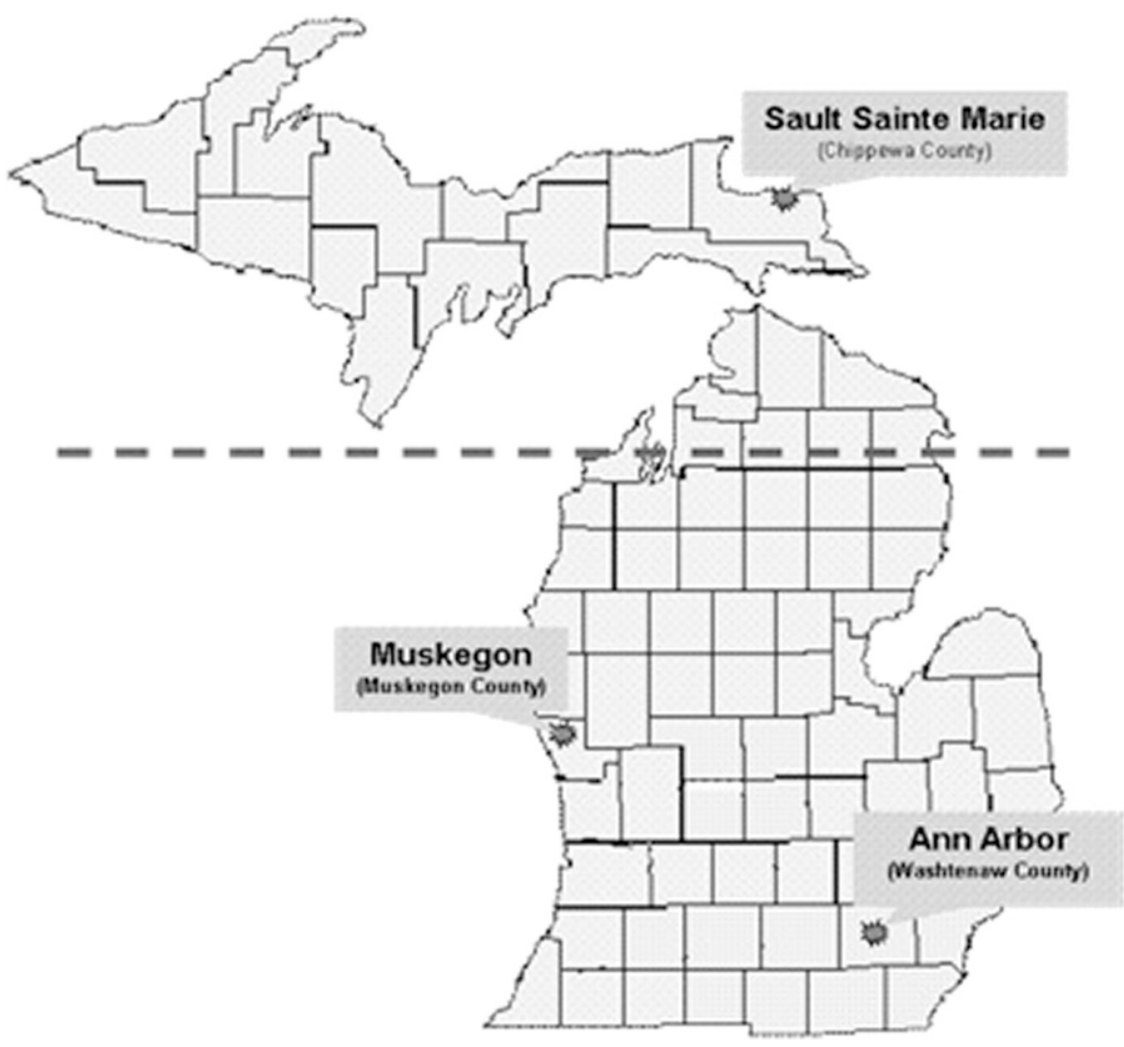

Fig. 1. Sites of farmers' markets used by farmers participating in Michigan State University research study. Three farmers sold at each of these three sites. researchers permission to report data from the budgets and used activity and harvest $\log$ forms to track activities, expenses, dates, and sales. They were asked to summarize these data and submit a report form for each month containing total revenue, labor parsed by activity (i.e., planting, weeding, harvesting, packing, etc.), and costs by category (i.e., seeds, fertility inputs, packing supplies, etc.). It was intended that the nine farmers would begin record keeping on the same month and continue for 30 months. However, because of variations in the farmers' time to construct and begin using the hoophouse, the first month of data varies from Aug. 2006 to Feb. 2007. One farmer erroneously stopped recording data after 29 months. The months of reported data for each farmer are illustrated in Fig. 2. Each farmer chose his own crop mix and allocation of space to each crop; the researchers believed the farmers were best able to determine which crops best suited the farms' marketing goals. All farmers used the structure to grow a variety of horticultural crops depending on season, markets, and customer preferences.

Several related assumptions guided the analysis. First, researchers were only interested in data related to the hoophouse. Any revenues, costs, labor, or other data from elsewhere on or off the farm were not considered. Second, since the hoophouses were placed on existing farms, fixed and equipment costs (land, taxes, tractors, additional buildings, etc.) were not considered unless they were specifically purchased for the hoophouse. The farmers were

Table 2. Selected demographic farmer attributes, farm business descriptors, and self-reported behavioral factors of nine Michigan hoophouse case studies.

\begin{tabular}{|c|c|c|c|c|c|c|c|c|c|c|}
\hline $\begin{array}{l}\text { Farmer } \\
\text { identification } \\
\text { code }\end{array}$ & $\begin{array}{l}\text { Age } \\
(\mathrm{yr})\end{array}$ & $\begin{array}{c}\text { Education } \\
\text { level } \\
(\mathbf{y r})^{\mathrm{z}}\end{array}$ & $\begin{array}{c}\text { Farm } \\
\text { experience } \\
(y \mathbf{y})\end{array}$ & $\begin{array}{c}\text { Greenhouse } \\
\text { experience } \\
(y r)\end{array}$ & $\begin{array}{c}\text { Total } \\
\text { area } \\
\text { farmed } \\
(\text { acres })^{\mathrm{y}}\end{array}$ & $\begin{array}{l}\text { Specialty } \\
\text { crop area } \\
\text { farmed } \\
\text { (acres) }^{\mathrm{y}}\end{array}$ & $\begin{array}{c}\text { Michigan } \\
\text { county }\end{array}$ & $\begin{array}{c}\text { Median } \\
\text { county } \\
\text { income } \\
(\$)^{x}\end{array}$ & $\begin{array}{c}\text { Record } \\
\text { keeping } \\
(2-10 \text { scale })^{\mathrm{w}}\end{array}$ & $\begin{array}{c}\text { Farmer } \\
\text { markets } \\
\text { (no.) }\end{array}$ \\
\hline $\mathrm{F} 2$ & 34 & 12 & 20 & 0 & 30 & 1.5 & Oceana & 40,872 & 10 & 1.5 \\
\hline F3 & 49 & 16 & 25 & 14 & 200 & 80 & Washtenaw & 59,126 & 5.5 & 18 \\
\hline F6 & 58 & 13 & 38 & 3 & 0.5 & 0.5 & Muskegon & 41,274 & 5 & 1 \\
\hline F7 & 57 & 12 & 15 & 15 & 5 & 5 & Newaygo & 44,157 & 4 & 1 \\
\hline F8 & 47 & 18 & 27 & 7 & 0.25 & 0.25 & Mackinac & 37,928 & 10 & 2 \\
\hline F9 & 69 & 13 & 15 & 0 & 1.25 & 0 & Washtenaw & 59,126 & 10 & 3 \\
\hline
\end{tabular}

${ }^{\mathrm{z}}$ Twelve years is high school graduate or equivalent.

${ }^{\mathrm{y}} \mathrm{l}$ acre $=0.4047 \mathrm{ha}$.

${ }^{x}$ USDA, 2010

"Sum of two self-assessment measures: 1-5 for on time, 1-5 for correct format. 
asked to judge whether they would have purchased a specific item (e.g., a seeder) if they had not acquired the hoophouse.

Production technical assistance was provided to farmers in the form of a sample seed order, schedules for year-round production in hoophouses based on actual planting dates generated at the MSU Student Organic Farm, and course pack materials from MSU courses, which included supplemental articles. In addition, technical assistance was provided through phone discussions and emails, with individual farmers and quarterly visits to all sites. Farmers were also provided with contact information for each of the farmers in the project, so that they could interact with one another, if desired.

Data were used to calculate answers to each of the specific research questions stated above. Total construction hours were recorded by farmers and summarized by the researchers. Total sales revenues and input costs were used to calculate net revenue (revenue minus cost). Data are reported as occurring in Year 1 (the first 12 months of data recorded by each farmer), Year 2 (months 13-24), and Year 3 (the remaining months, totaling between 5 and 8 months). The total cost of the hoophouse structure (estimated at $\$ 10,000$ ) was divided by the average monthly net revenue for each farmer (over the course of the study) to calculate months to pay back the initial investment. Net revenue was divided by total labor hours over the course of the study (not including construction labor) to derive effective wage as a measure of returns to labor. Finally, labor hours were tabulated by month to measure labor allocation.

\section{Results and discussion}

Construction labor. Construction labor data are composed of total person labor hours as well as subdivisions of hours for site preparation, frame assembly, polyethylene covering attachment, and other, which includes activities such as electric and water installation. Six-foot ground posts were driven $4 \mathrm{ft}$ in the ground manually with a fence post-pounder and sledge hammer and were not cemented. Not requiring the ground posts to be cemented in place decreased construction time. The Rimol construction manual for this size and model suggests $\approx 100$ total person hours for expert level construction. Total person hours for construction across all nine houses averaged $237 \mathrm{~h}$, with a range of 114-420 h. Site preparation ranged from $0 \mathrm{~h}$, for a structure built over a field already in production, to $134 \mathrm{~h}$, with a mean of $47 \mathrm{~h}$. Frame construction ranged from 91 to $228 \mathrm{~h}$, with a mean of $136 \mathrm{~h}$. Polyethylene attachment, which includes two layers on the roof and a single sheet on each end wall, ranged from 10 to $97 \mathrm{~h}$, with a mean of 47 person hours. Other labor hours, which include water and electricity to the site in some cases, ranged from 0 to $23 \mathrm{~h}$, with a mean of 6 person hours (Fig. 3 ).

Site preparation, including weed and fertility management, is a key step for long-term successful growing in these structures (Montri and Biernbaum, 2009). One strategy, which resulted in zero total site preparation hours, was to construct the hoophouse over an existing planting or field. Although site preparation may be time consuming, growers stated that it is an opportunity to manage and control weeds before construction. This cultural practice results in less time spent managing weeds later and less plant competition with subsequent plantings in the hoophouse. Despite a verbal recommendation during early conference calls for emphasis on site preparation and building soil organic matter during the summer before construction, growers at some locations did not prepare the site before construction, which delayed and limited spring planting. At least two sites experienced challenges with poor water drainage away from the structure that likely limited productivity.

All houses were identical, which resulted in trainer experience increasing as additional structures were completed. An identical structure that was not part of the study was built at MSU before the first training build. The first training build used the greatest person hours at $420 \mathrm{~h}$ total, $228 \mathrm{~h}$ of which were allocated to frame construction. This site had unusual clay

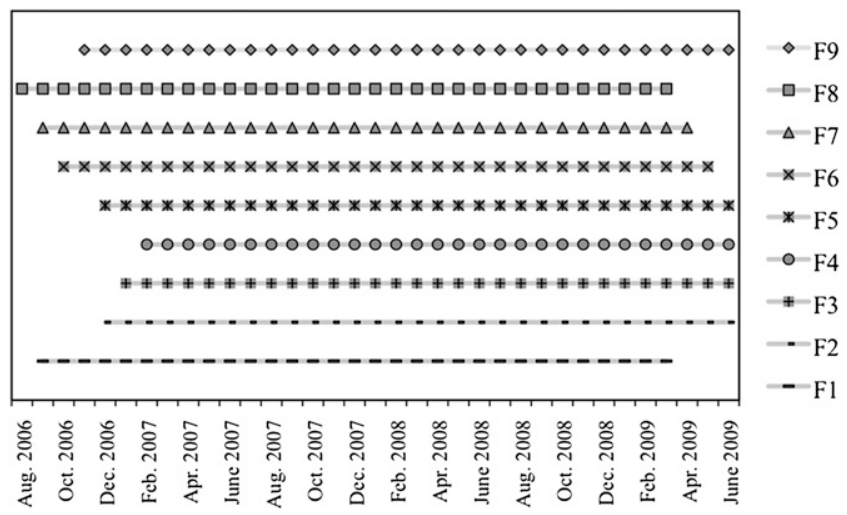

Fig. 2. Range of months for which each of nine participating farmers reported revenue, cost, and labor data associated with growing in hoophouses as part of Michigan State University-led study.

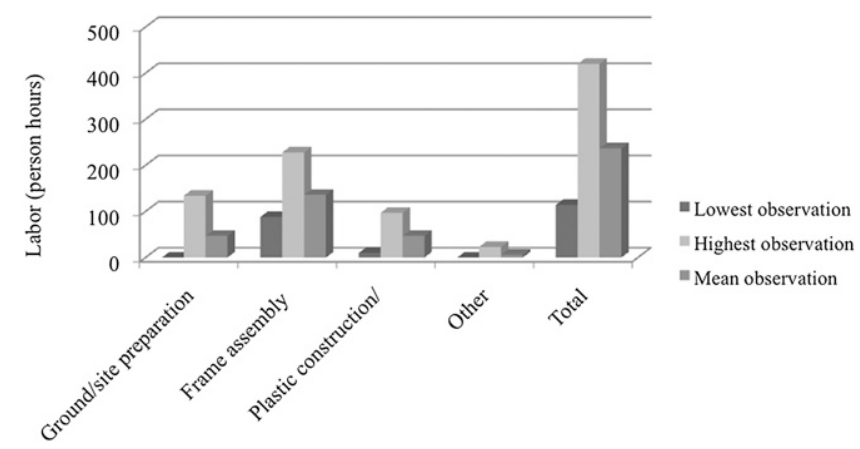

Fig. 3. Maximum, minimum, and mean person hours required to construct hoophouses as reported by nine participating farmers in Michigan. Data are reported by major activity categories and in total. 
subsoil that slowed ground postplacement compared with any of the other sites.

Following construction of all hoophouses, farmers who were part of the training build but were responsible for constructing their own hoophouses, stated that having an experienced person as part of the build decreased construction time dramatically. Three additional sites (which are not included in this study) were added in Year 2, with the 2007 training build completed in $\approx 100 \mathrm{~h}$; the same time suggested by the manufacturer for an expert crew to construct this specific hoophouse. The crew for this build consisted of four persons with prior greenhouse- or hoophouse-building experience. Use of a gas-powered post-pounder in later training builds reduced construction time and labor.

Gross sales, reVenue, AND RETURN TO LABOR. Gross sales are defined as total sales, whereas net income is defined as total sales minus total costs. Gross sales by farm over the period of the study ranged from $\$ 2401$ to $\$ 20,193$, with a mean of $\$ 9195$. Net income ranged from $\$ 351$ to $\$ 14,771$, with a mean of $\$ 6215$ (Table 3 ). The average monthly net income for all farmers over the study period ranged from $\$ 11$ to $\$ 553$, with an average of $\$ 201$. Year 2 (months 13-24 of operation) marked the highest average net income and was the most profitable period for most farmers. Two farmers (F2 and F9) averaged more than $\$ 475$ of net revenue per month over the course of the project; the remaining seven farmers averaged monthly net revenues of only $\$ 111$. Crop selection can have a major impact on gross sales. The original intent of farmers was to include labor and sales record per crop, but a short way into the study, the protocol was changed due to farmers' inability to consistently and credibly record these data; the relationship between crop selection and gross or net income is not available but is recommended as a topic for future study.

YEARS FOR PAYBACK. Initial investment for materials per structure is approximated at $\$ 10,000$ at the time of project initiation. Based on quotes received from four suppliers before purchase, with differences in manufacturers, structural steel, layers of plastic film and delivery costs, the purchase price could have fluctuated by as much as $25 \%$. A main focus of this project was to record the time required to generate enough net income to pay back the initial structure's investment and begin to realize a profit. Based on average monthly income, if these farmers devoted all net income to paying back the original $\$ 10,000$ investment (with no interest), two farmers would have paid back the investment in 2 years or fewer (Fig. 4), while one would take more than 70 years. The average payback for the nine farmers is 4.2 years.

RETURNS TO OWNER OPERATOR AND FAMILY LABOR. The effective hourly wage (net revenue divided by total hours) for these farmers ranges from $\$ 0.28$ to $\$ 12.77$ per hour, with an average of $\$ 6.24$ per hour (Table $4)$. The most common pattern was an increase from Year 1 to Year 2 followed by a decrease in Year 3. One farmer's effective wage declined each year and in two cases, it increased each year. As of Apr. 2010, the minimum wage in Michigan is $\$ 7.40$ per hour. Only four farmers earned an effective wage greater than $\$ 7.40$ per hour.

LABOR allocation. As seen in Table 4, there is an almost 10 -fold difference in the range of total labor hours devoted to the hoophouse over the study period. F3 and F4 both used hired labor (reporting $50 \%$ of total labor as hired), which accounts for low totals. Three farmers (F1, F6, and F8) with a high number of labor hours earned among the lowest effective wages.

As shown in Fig. 5, the total average number of hours per month devoted to hoophouse labor was greatest during warm weather months when outdoor crops potentially compete for farmers' attention. Total labor hours tended to be lowest in cool-season months when the farmers' overall workload was presumably less.

There is a broad range of construction hours, gross and net income, return to labor, and years to pay back in the study period. Much of this can be attributed to each farmer's use of the structure, time management practices, and marketing practices and opportunities. Prior experience building these structures and prior construction experience appears to greatly accelerate construction. Structures were delivered early enough (early August) to allow construction and planting during the early fall for a winter harvest, but limited preconstruction site preparation, the time invested in construction, and other farm activities prevented planting until the following spring season for all

Table 3. Economic outcomes of nine Michigan hoophouse case studies. Gross and net sales revenues are reported by year of operation and by monthly average of project duration.

\begin{tabular}{|c|c|c|c|c|c|c|c|c|c|}
\hline $\begin{array}{l}\text { Farmer } \\
\text { identification } \\
\text { code }\end{array}$ & $\begin{array}{c}\text { Gross } \\
\text { income } \\
\text { Year } 1 \\
(\$) \\
\end{array}$ & $\begin{array}{c}\text { Net } \\
\text { income } \\
\text { Year } 1 \\
(\$) \\
\end{array}$ & $\begin{array}{c}\text { Gross } \\
\text { income } \\
\text { Year } 2 \\
(\$) \\
\end{array}$ & $\begin{array}{c}\text { Net } \\
\text { income } \\
\text { Year } 2 \\
(\$) \\
\end{array}$ & $\begin{array}{c}\text { Gross } \\
\text { income } \\
\text { Year } 3 \\
(\$)\end{array}$ & $\begin{array}{c}\text { Net } \\
\text { income } \\
\text { Year } 3 \\
(\$) \\
\end{array}$ & $\begin{array}{l}\text { Time in } \\
\text { Year } 3 \\
(\text { mo. })\end{array}$ & $\begin{array}{l}\text { Avg } \\
\text { monthly } \\
\text { income } \\
\text { Year } 3 \\
(\$)\end{array}$ & $\begin{array}{c}\text { Avg } \\
\text { monthly } \\
\text { income, } \\
\text { all mo. } \\
(\$)\end{array}$ \\
\hline Fl & 3,590 & 2,933 & 4,813 & 2,914 & 490 & 79 & 6 & 13 & 198 \\
\hline $\mathrm{F} 2$ & 3,440 & 2,247 & 10,995 & 9,953 & 5,758 & 4,571 & 6 & 717 & 553 \\
\hline F3 & 3,697 & 2,108 & 2,573 & 1,759 & 0 & -800 & 6 & -133 & 102 \\
\hline F5 & 1,487 & 1,166 & 3,740 & 2,979 & 1,736 & 1,380 & 7 & 197 & 178 \\
\hline F6 & 507 & -792 & 1,073 & 680 & 821 & 462 & 8 & 58 & 11 \\
\hline F7 & 1,277 & -296 & 2,242 & 2,035 & 896 & 438 & 8 & 55 & 68 \\
\hline F8 & 3,303 & 408 & 3,386 & 1,793 & 2,433 & 2,065 & 8 & 258 & 133 \\
\hline F9 & 7,031 & 4,809 & 7,862 & 6,894 & 4,004 & 3,556 & 8 & 444 & 477 \\
\hline Avg & 2,959 & 1,463 & 4,443 & 3,493 & 1,793 & 1,258 & 7 & 169 & 201 \\
\hline
\end{tabular}


but two farmers, F7 and F8. These farmers were not among the highest effective wage or net income earners, suggesting that other factors drive profitability. Specifically, while the original intent was a test of economic performance of the technology (hoophouses), the researchers' results and experiences led to a different emphasis: understanding how human behavior, particularly farm business management, impacts the profitable use of this tool.

From Year 1 to Year 2, average monthly income per farmer more than doubled from \$122 per month to $\$ 291$ per month, clearly demonstrating an important learning curve. However, in Year 3, the average monthly income dropped to $\$ 169$ per month. This drop can largely be attributed to farmers F3 and F4, both

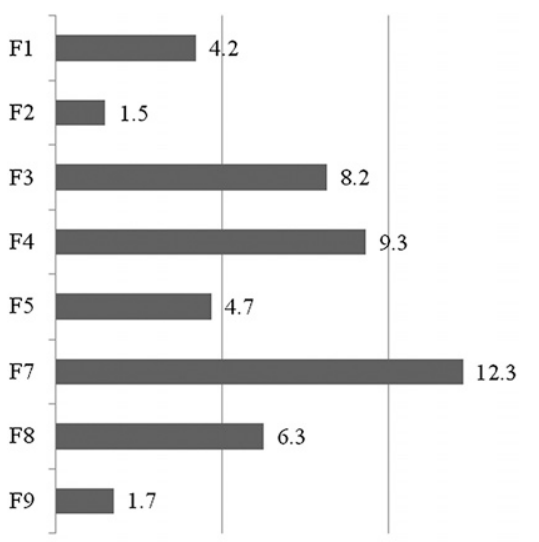

- Time to payback (y ears)

Fig. 4. Years to pay back a $\$ 10,000$ hoophouse, given average monthly net income to date for farmers in a Michigan hoophouse case study. Fl to F9 are farmer identifier codes. F6 was omitted as outlier $(\approx 70$ years to payback). of whom recorded no gross sales in the portion of Year 3 where they were still reporting data. F2 and F9, however, posted profits similar to the first 2 years in the months in Year 3 where they were still recording data. All nine farmers marketed through farmers' markets, but markets for these farmers vary by location. Farmers with the four highest effective wages, F2, F3, F4, and F9, all vend at markets that function year-round, although the farmer with lowest effective wage (F6) also attends a year-round market. There was also wide variation in median household income per county, with the three farmers in the highest income (F3, F4, and F9) area making considerably less than F2, who farmed in the second poorest county. The market where F2, F3, and F9 sell is located in a relatively wealthy college town with an active local food culture. There was also notable variation in the total acres farmed and the amount of additional acreage dedicated to specialty crops.

When examining labor allocation in relation to time of year, it is clear that farmers allocated higher amounts of time to hoophouse labor in the warmer months, or traditional growing season, when the opportunity cost of their labor was highest. In theory, hoophouses can lessen summer workloads, although on average this group of farmers chose to use more labor in summer months in Year 2 and Year 3 (than the first year). These efforts question whether the hoophouse lessens farmers' summer workload. However, it is important to highlight that, with off-season (winter) income, it may be possible to adjust summer workloads and extend income throughout the year. There is also the potential that farmers will continue to work extended hours in the spring-fall traditional farming season while also adding hours in the winter, so that instead of the same income being extended over 12 months, there would be a similar summer income with additional winter income adding to total farm revenue. An additional possibility is that farmers will choose extended warm-season crop production without adopting yearround production, which is what seems to be the case for many farmers in this study.

Experienced hoophouse growers have suggested minimum gross sales of $\$ 5 / \mathrm{ft}^{2}$ per year (Coleman, 1995). None of the published tomato budgets (Table 1) earn this total, although this total could be achieved with additional crops planted and harvested in a given year (in addition to the tomato crop). As stated earlier, these projections may be more possible for experienced grower in established markets but less attainable during the few first years for those new to year-round production. Eight of the nine growers in this study had no experience with year-round growing in unheated greenhouses, while the ninth had experience on a much smaller scale. These nine farmers averaged \$1.24/ $\mathrm{ft}^{2}$ per year (average monthly gross income $\times 12$ divided by $2880 \mathrm{ft}^{2}$ ), with the highest earner grossing $\$ 2.80 / \mathrm{ft}^{2}$ per year.

The earnings of these hoophouses can be compared with field vegetable and greenhouse floriculture production. In 2009, the average Michigan vegetable farm earned (gross) \$2398 per acre $(\approx \$ 257$ million over 107,000 acres) (USDA, 2010). Seven of the nine farmers averaged more than this amount per year in one hoophouse alone. Many Michigan vegetables are sold wholesale or for processing, rather than through direct marketing outlets

Table 4. Effective wages and total labor efforts of nine Michigan hoophouse case studies.

\begin{tabular}{|c|c|c|c|c|c|}
\hline $\begin{array}{l}\text { Farmer identification } \\
\text { code }\end{array}$ & $\begin{array}{c}\text { Effective wage, } \\
\text { Year } 1(\$ / \mathrm{h})\end{array}$ & $\begin{array}{c}\text { Effective wage, } \\
\text { Year } 2(\$ / \mathrm{h})\end{array}$ & $\begin{array}{c}\text { Effective wage, } \\
\text { Year } 3(\$ / \mathrm{h})\end{array}$ & $\begin{array}{c}\text { Effective wage, } \\
\text { overall }(\$ / \mathrm{h})\end{array}$ & $\begin{array}{l}\text { Labor } \\
(100 \mathrm{~h}) \\
\end{array}$ \\
\hline Fl & 3.42 & 1.63 & 0.15 & 1.93 & 30.75 \\
\hline F3 & 12.20 & 18.01 & -8.18 & 8.27 & 3.71 \\
\hline $\mathrm{F} 4$ & 4.39 & 16.37 & -9.79 & 7.92 & 3.28 \\
\hline F5 & 5.15 & 9.07 & 6.99 & 7.28 & 7.52 \\
\hline F8 & 0.67 & 3.20 & 11.03 & 2.91 & 14.65 \\
\hline F9 & 10.19 & 10.26 & 10.57 & 9.59 & 15.91 \\
\hline
\end{tabular}




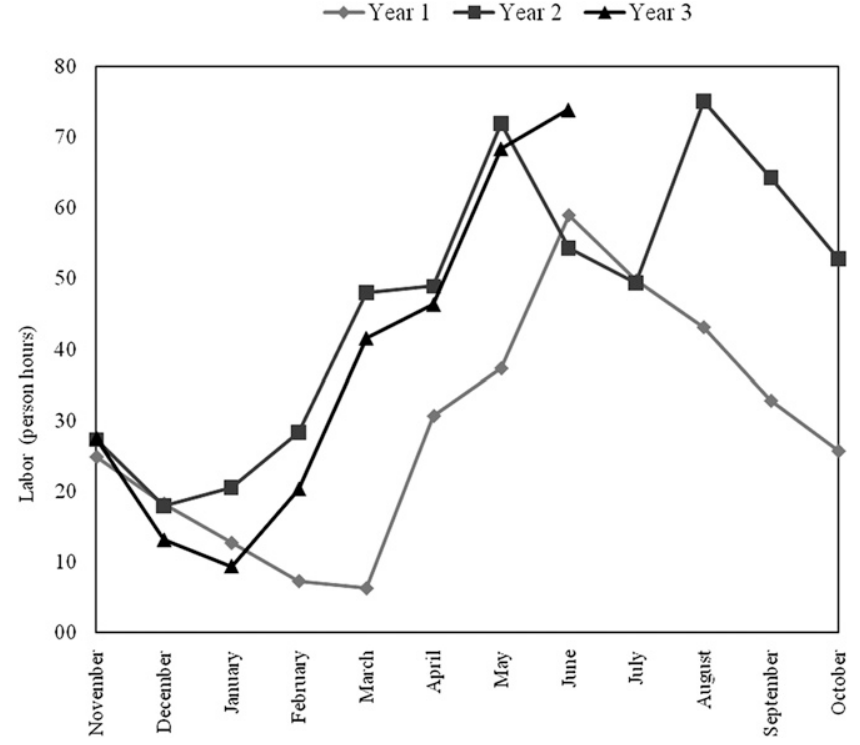

Fig. 5. Monthly allocation of labor (person hours per month), average (mean) for all nine Michigan farms, over the first 2 1/2 years of the project.

used by these hoophouse farmers. The ability to generate income on small areas is important, given the growing interest in agriculture and the cost barriers associated with larger land purchases and management. Greenhouse farm gate value for Michigan where many greenhouses are only used for part of the year averages around $\$ 350,000$ /acre (USDA, 2010). Uva and Richard's (2002) greenhouse study in New York found greenhouses gross $\approx \$ 0.436 / \mathrm{ft}^{2}$ per week, equaling $\approx \$ 23 / \mathrm{ft}^{2}$ or $\$ 1$ million/acre per year. Lastly, the project researchers have noticed a relationship between the timeliness and completeness of data collection and earnings, with those case study farmers who submitted data in a timely and organized manner tending to earn higher net revenues. The two highest earners (both in net revenue and effective wage), F2 and F9, both had perfect self-reported data gathering performance. F6 had one of the poorest self-reported measure of data collection performance and the poorest economic performance. Farmers interviewed commonly suggest that attention to detail, particularly regarding schedules for planting and harvesting, and "staying on top" of weeding and harvesting, is a key to success in hoophouses (Conner and Montri, 2008). While the number of case studies $(N=9)$ and duration of study makes it difficult to make this case in a statistically significant manner, it makes intuitive sense and echoes the old adage "you can't manage what you do not measure."

\section{Conclusion}

Hoophouses have the potential to contribute to farm profitability by providing new market and labor allocation opportunities: this study measures the economic outcomes of hoophouses used by novices. Under some management practices, the hoophouse structures used in this study could be paid back in 2 years. Returns to labor were generally below minimum wage, mirroring overall difficulty in farm profitability.

Based on the results of this study, hoophouses can be a profitable tool in Michigan. Given the wide variation in hoophouse farmer performance, the relatively small sample, and the self reporting, any generalizations based on these data should be limited. It is also unknown whether not having to pay for the hoophouse out of pocket (recall that the structures were purchased with grant money and given to farmers in exchange for their participation in the research) may have diminished the farmers' urgency to maximize the flow of profits. Nonetheless, these findings highlight the range of economic impacts hoophouse novices may encounter when adopting this tool.

Future research directions include further investigation into factors contributing to profitable use of hoophouses, particularly farm management practices such as crop selection and scheduling and labor allocation to specific tasks and over the course of the year. Such on-farm findings can complement universitybased trials and inform profitable use of this tool.

\section{Literature cited}

Blomgren, T. and T. Frisch. 2007. High tunnels: Using low-cost technology to increase yields, improve quality, and extend the season. 13 July 2010. <http:// www.uvm.edu/sustainableagriculture / Documents/HighTunnels.pdf $>$.

Bullen, S.G. 2009. High tunnel budgets. 13 July 2010. <http://www.cefs.ncsu. edu/newsevents / eventarchives /2009/ sosa2009/hightunnel/hightunnelbud gets02172009.pdf>.

Byczynski, L. 2003. The hoophouse handbook: Growing produce and flowers in hoophouses and high tunnels. Fairplain Publ., Lawrence KS.

Carey, E., L. Jett, W.J. Lamont, T. Nennich, M. Orzalek, and K.A. Williams. 2009. Horticultural crop production in high tunnels in the United States: A snapshot. HortTechnology 19:37-43.

Cheng, M. and W. Uva. 2008. Removing barriers to increase high tunnel production of horticultural commodities in New York. Economic and marketing study final report. 13 July 2010. <http://www.hort.cornell.edu/ hightunnel/about/research/economics/ removing_barriers_uva_cheng.pdf $>$.

Coleman, E. 1992. Four season harvest. Chelsea Green Publishing, White River Junction, VT.

Coleman, E. 1995. The new organic grower. Chelsea Green Publishing, White River Junction, VT.

Coleman, E. 2009. The winter harvest manual: Year round vegetable production using deep organic techniques and unheated greenhouses. Chelsea Green Publishing, White River Junction, VT.

Conner, D., W. Knudson, M. Hamm, and C. Peterson. 2008. The food system as an economic driver: Strategies and applications for Michigan. J. Hunger Environ. Nutr. 3:371-383.

Conner, D. and A. Montri. 2008. Hoop houses for season extension: Are they right for you? 13 July 2010 . <http:/ / www. ipm.msu.edu/new-ag/issues08/8-12. htm>.

Demchak, K. 2009. Small fruit production in high tunnels. HortTechnology 19: 44-49. 
Foord, K. 2004. High tunnel budgets and marketing. 13 July 2010. <http:// www.extension.umn.edu/distribution/ horticulture/components/M121812.pdf $>$.

Giacomelli, G.A. 2009. Engineering principles impacting high-tunnel environments. HortTechnology 19:30-33.

Heindenreich, C., M. Pritts, M.J. Kelly, and K. Demchak. 2008. High tunnel raspberries and blackberries. 13 July 2010. <http://www.fruit.cornell.edu/ Berries/bramblepdf/hightunnelsrasp.pdf $>$.

Lamont, Jr., W.J., M.D. Orzolek, E. Holcomb, R. Crassweller, K. Demchak, E. Burkhart, L. White, and B. Dye. 2002. Penn State high tunnel extension program. HortTechnology 12:732-735.

Lancaster, K.L. 1974. A new approach to consumer theory. J. Polit. Econ. 74:132157.

Montri, A. and J.A. Biernbaum. 2009. Management of the soil environment in high tunnels. HortTechnology 19:34-36.
Porter, M.E. 1985. Competitive advantage: Creating and sustaining superior performance. Free Press, New York.

Swenson, D. 2006. The economic impacts of increased fruit and vegetable production and consumption in Iowa: Phase II. 13 July 2010. <http://www.leopold. iastate.edu/pubs/staff/health/health. htm>.

U.S. Department of Agriculture. 2007a. Net cash farm income of operations and operators: 2007 and 2002. 13 July 2010. <http://www.agcensus.usda. gov/Publications/2007/Full_Report/ Volume_1,_Chapter_l_State_Level/ Michigan/st26_1_004_005.pdf>.

U.S. Department of Agriculture. 2007b. Net cash farm income of operations and operators: 2007 and 2002. 13 July 2010. <http://www.agcensus.usda. gov/Publications/2007/Full_Report/ Volume_1,_Chapter_1_US/st99_1_004_ 005.pdf>.
U.S. Department of Agriculture. 2010. County-level unemployment and median household income for Michigan. 13 July 2010. <http://www.ers.usda.gov/data/ unemployment/RDList2.asp?ST=MI>

Upson, S. 2009. Economic feasibility of hoop house tomato production. 13 July 2010 . <http://www.noble.org/ag/ Horticulture/HoopTomato/Index.htm>.

Uva, W. and S. Richard. 2002. New York greenhouse business summary and financial analysis, 2000. 5 Sept. 2010. <http://www.aem.cornell.edu/outreach/ extensionpdf/2002/Cornell_AEM_ eb0203.pdf>.

Waterer, D. 2003. Yields and economics of high tunnels for production of warmseason vegetable crops. HortTechnology 13:339-342.

Wiediger, P. and A. Wiediger. 2003. Walking to spring: Using high tunnels to grow produce 52 weeks a year. Au Naturel Farm, Smiths Grove, KY. 